\title{
Morning Aps: The Game Rules Learning Application and Football Referee Signals
}

\author{
$1^{\text {st }}$ Fahrial Amiq \\ Jurusan Pendidikan Jasmani, Kesehatan dan Rekreasi, Fakultas \\ Ilmu Keolahragaan \\ Universitas Negeri Malang \\ Malang, Indonesia \\ fahrial.amiq.fik@um.ac.id
}

\author{
$2^{\text {nd }}$ Prayogi Dwina Angga \\ Jurusan Ilmu Pendidikan, Fakultas Keguruan dan Ilmu Pendidikan \\ Universitas Mataram \\ Mataram, Indonesia \\ prayogi.angga@unram.ac.id
}

\begin{abstract}
The increasing demands in this digital era encourage education to accomplish the learning process by integrating with technology. This study aimed to develop learning products for game rules and football referee signals presented in mobile learning for students of the Department of Physical Education, Health, and Recreation. The research and development model was adapted from Lee \& Owens' (2004) research and development model, which consisted of 1) The analysis is divided into two parts, needs analysis and front-end analysis, 2) The planning phase, 3) Product development, 4) Implementation of product development results), and 5) Evaluation of goal achievement factors in development. Based on the results of learning experts' validation, football referee experts, small group trials, and field-tests, it can be inferred that the learning products of game rules and football refereeing signals for mobile learning are in excellent criteria and suitable to use by students in the learning process. This development product is expected to guide students in learning game rules and football referee signals.
\end{abstract}

Keywords - football, game rules, learning, mobile learning, referee signals.

\section{INTRODUCTION}

The football coaching course is a compulsory subject that must be taken by students of the Faculty of Sports Science majoring in Physical Education and Health. The football coaching course contains the theory and practice of refereeing, which aims to equip students to get involved in the world of football, especially refereeing. During the period, the coaching carried out in the football subject still uses conventional learning and lacks a touch of technology; thus, it has many obstacles, from academic material missed during the meetings, such as when lecturers are absent or incomprehensible by students, the limited brain's memory storage capacity, the variety of students' characteristics, and the limited course time. Therefore, it is necessary to have an innovation that can reduce these problems by utilizing technology.

In the last few decades, the use of mobile devices such as smartphones or tablets has spread rapidly at an unprecedented rate. It is unveiled that $95 \%$ of the global population lives in some areas already covered by cellular networks [1]. There is even a rapid development of device ownership among adult users who own more than one mobile device [2]. The use of smartphone/tablet technology has a percentage of $50.08 \%$ or half of Indonesia's population based on data from the Indonesian Internet Service Providers Association in 2017 [3]. The data demonstrates that the average of Indonesian people has at least a smartphone/tablet, which is easier to use and carry in daily activities. The largest demographic of mobile devices users, such as smartphones/tablets, is in the age range from 18 to 29 [4], [5], which means university students' age. It illustrates that mobile devices are inseparable from students.

Learning that is integrated on a smartphone/tablet or better known as mobile learning, has a larger percentage of usage because smartphones are used daily. Therefore, students can access it in unlimited time. Also, a learning process that is collaborated with technology is more efficient, effective, varied, independent, attractive, and easy to understand, including at the university level [6], [7], [7]-[9]. Recent empirical evidence suggested that mobile learning can be utilized to support student learning in higher education settings [10], [11].

Mobile learning is a term to denote learning that involves the use of a mobile device. It is a learning innovation in the form of gadgets that students can incorporate to enable learning anytime and anywhere [12]. The use of mobile learning as a means of learning can be realized with a mobile application (application in a mobile phone). It is a learning that lets students not stay in one place or join learning activity when they employ technology in their mobile devices [13]. In this concept, mobile learning brings the benefits of the availability of teaching materials that can be accessed and the visualization of exciting material. Based on this definition, mobile learning is a learning model that utilizes information and communication technology. Furthermore, m-learning or mobile learning refers to the use of gadgets such as PDAs (Personal Digital Assistants), mobile phones, laptops, and information technology devices that will be widely used in the teaching and learning process.

A mobile application is a software that is designed to reach the broadest possible user with a limited time through the installation of applications on mobile devices, i.e., iOS, Android, and Windows phones [14]. A mobile application is an application that facilitates users to perform all activities 
efficiently [15]. The existence of progress must be utilized to improve the quality of learning. The use of mobile applications in learning allows students to access material and helps educators see the students' learning progress [16]. Another use of mobile applications in learning can also increase student contributions to independent learning [7]. Student achievement can be enhanced through its other functions for ubiquitous learning and easier access to learning resources compared to traditional learning [17]. The applications are expected to increase students' competence, autonomy, motivation, and positive achievement because they provide information and feedback constructively [18].

\section{MethodS}

The development of a product requires a systematic step arrangement; therefore, a product can be created that can be a solution and a sophistication. The research and development model was adapted from Lee \& Owens' (2004) research and development model, which consists of 1) The analysis is divided into two parts, needs analysis and front-end analysis, 2) Design of the planning phase, 3) Product development, 4) Implementation of product development results), and 5) Evaluation of goal achievement factors in development.

The research subjects in this development research include 200 students taking the football coaching course. Furthermore, the expert subjects as collaborators in the planning and product development phase involve learning experts with minimum educational qualifications of master's degree and football referees with minimum qualifications of C3 National level, as evidenced by their certificates. In the application phase of product development results, the subjects categorized as 40 students in the first phase (small groups) and 160 students to apply product development results in large groups.

The data collection instrument used a qualitative and quantitative approach in the form of a questionnaire. The questionnaire was used to collect qualitative and quantitative data from needs analysis, expert evaluation, small group trials, and large group trials to determine product eligibility percentage. The percentage of product eligibility is calculated using the total score obtained, divided by the maximum total score, and multiplied by $100 \%$. The eligibility criteria are illustrated in Table 1.

TABLE I. ELIGIBILITY CRITERIA

\begin{tabular}{|c|c|c|}
\hline No & Percentage (\%) & Category \\
\hline 1 & $0-20 \%$ & Poor \\
\hline 2 & $21 \%-40 \%$ & Fair \\
\hline 3 & $41 \%-60 \%$ & Average \\
\hline 4 & $61 \%-80 \%$ & Good \\
\hline 5 & $81 \%-100 \%$ & Excellent \\
\hline
\end{tabular}

\section{RESULTS}

The needs analysis stage was carried out by observing football learning conducted in the Department of Physical
Education and Health. Based on the results of observations, it revealed that most students have Android-based smartphones. Smartphones have not been used optimally. Additionally, most students use smartphones to open applications such as games, instant messenger applications (e.g., WhatsApp), and so on during the learning process. This might cause the learning process to be less effective. In addition, books in printed form are still the primary reference as a learning resource but are not incorporated by a high level of interest in reading and understanding the book's contents. This analysis's results became a reference in developing mobile-based learning media that is more faultless, varied, effective, attractive, and comfortable to be used in the learning process. Another alternative is making offline-based applications to allow students to study anywhere and anytime using smartphones without an internet connection.

The planning and product development stage is carried out by involving learning experts and licensed football referees. Experts then validate the results of the designs made by researchers as a step to evaluate the initial product and provide input for improvement by conducting a conceptual analysis, which is then revised. In this study, expert judgment was accomplished to obtain input on the product design of game rules and mobile-based learning of football referee signals. Evaluation is conducted by showing the product design developed in a game rules application and mobile-based learning of football referee signals, integrated by an evaluation sheet for experts. The evaluation sheet is a questionnaire containing instructional criteria, presentation criteria, and suggestions and comments on the product of the development of game rules and mobile-based learning of football referee signals.

The validation of learning experts is carried out to explore 4 main aspects of the development of game rules products and mobile-based learning of football referee signals. The four aspects consist of attractiveness, accuracy, clarity, and suitability. Based on the results of the learning experts' judgment on game rules products and mobile-based learning of football referee signals performed by two learning experts, the total score of the assessment results is 430 from a maximum score of 500 or with a percentage of $86 \%$. When converted to the referee of predetermined criteria, the result score or percentage means that the product developed was in the "excellent" category, and it means the product developed is suitable for learning. The data analysis presented in the results of the licensed football referee expert-test displays the validation score of 189 from a maximum score of 200 or with a percentage of $94.5 \%$. Consequently, if the result of the percentage score is converted to the predetermined criteria, it can be concluded that the game rules products and mobilebased learning of football referee signals conform to the official game signals and rules.

The next stage is the implementation or application of the results of product development conducted in small groups involving 40 students, the purpose of this step is to find out whether the product design that has been developed by the researcher can be appropriately utilized and easy to implement 
by the target client (target clientele) or the students. Data collections in this step were observation and questionnaires, which were then analyzed descriptively. Based on the results of the assessment on small group trials conducted by students in the results of product development of game rules and mobile learning-based football referee signals, it can be indicated that the score of the assessment results is 1,812 from a maximum mark of 1,920 . Thus, it gains a percentage of 94,375 , which means that in general, the game rules products and mobile-based learning of football referee signals in this course fell into the excellent criteria, and there is no need for product revisions.

The development results of game rules products and mobile-based learning of football refereeing signals have been implemented on a small scale and revised. Moreover, the next stage is to conduct trials in large groups (field try-out). Field try-out was conducted by students of the Department of Physical Education, Health and Recreation, Faculty of Sport Science, State University of Malang. The number of subjects used in applying product development results in a large group was 160 people. Based on the assessment results on large group trials conducted by students on the results of the development of game rules and mobile-based learning of football referee signals. It can be concluded that the score of the assessment results is 7,055 from a maximum mark of 7,680 or the percentage of $91.861 \%$, which means that in general, the game rules products and mobile-based learning of football referee signals in this course fell into the excellent criteria and no need for product revisions. Based on the evaluation of the results in the product result implementation phase, the final product form is represented in Figure 1.

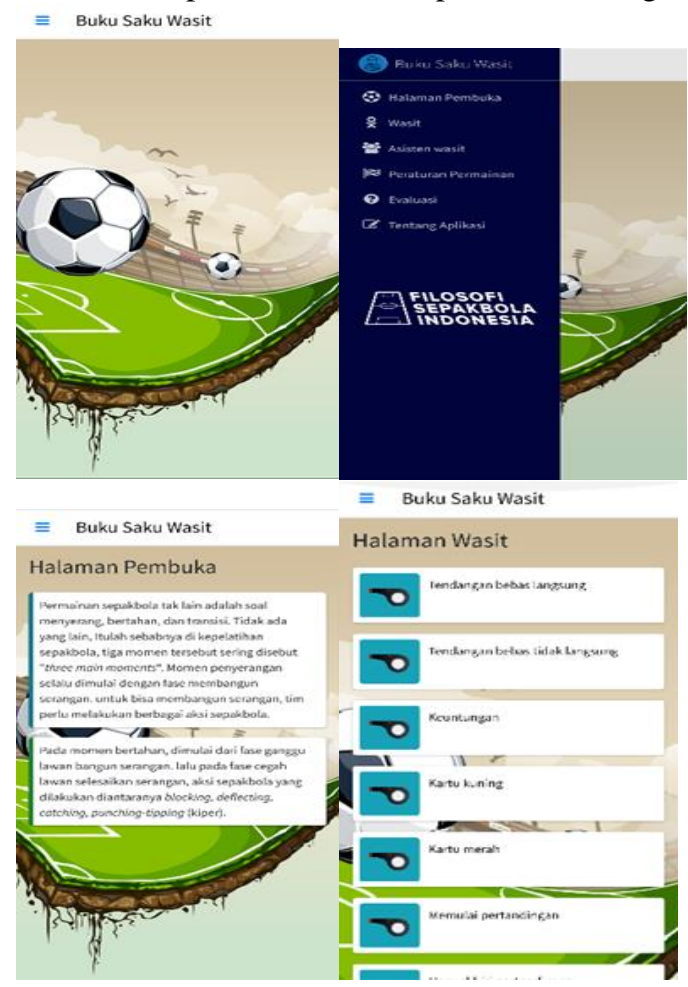

Fig 1. The Final Product of "Morning Aps"

\section{DISCUSSION}

The main objective of this research and development is to develop instructional media to create more meaningful and quality learning. The use of media in the learning process aims to facilitate the learning process; thus, it can occur efficiently and efficiently to improve educational quality [19]-[22]. Another support system of this learning application development is the ownership of mobile devices as we know that it has increased in the last few decades due to the progressively affordable prices of these devices. The escalating number of people who own and use mobile devices opens up opportunities of technology use in education. The use of mobile devices in the learning process also became known as mobile learning (m-learning) [23].

Mobile learning facilitates a learning process that lets learners not stay in one place or join learning activities in a traditional classroom. Those can occur due to technology use in mobile devices [13]. The presence of m-learning cannot replace the usual e-learning (electronic learning), moreover, replace face-to-face learning in a classroom [24]-[26]. Its presence is intended to complement existing learning and provides opportunities for students to relearn less mastered material anywhere and anytime [27]. This can certainly provide a different experience in the learning process for students [24], [28]-[31]. In the form of game rules products and mobile-based learning of football refereeing signals that have been developed, the learning media can be operated on Android-based mobile devices. Therefore, it can be accessed whenever and wherever.

The concept of mobile learning brings the benefits of teaching materials availability that can be accessed and interesting material visualization. It is crucial to note that not every teaching material is suitable for mobile learning [32]. Mobile learning is a learning model that utilizes information and communication technology. There are several main menus in this application, namely the homepage, the referee, the assistant referee, the game rules, evaluation, and the description of the application (about application). The "Referee," "assistant referee," "game rules" menus, which contain video and motion analysis on football game rules as competencies, are expected to be mastered by the user after studying the material presented in the application. The "evaluation" menu comprises some questions to test the user's understanding of the material. In addition, a brief description of the application is provided in the "About Application" menu. The existence of these menus allows users to choose interesting content to learn. This is following several criteria that make mobile learning effective [19], [28], [33]-[36].

The application developed in this study cannot be run on all mobile devices since it was set to work on Android-based mobile devices. Hence, it is hoped that the development of similar applications that can be managed on devices with different operating systems and on different learning materials. With the development of learning applications on mobile devices, it is expected to increase the advantages of mobile devices in education and support motivation for student learning. In addition, the application's existence like this can 
provide an outstanding and new learning experience for students.

\section{CONCLUSIONS}

The results of the development of game rules products and mobile-based learning of football referee signals, which are manifested in an Android-based application, have the following characteristics. 1) Game rules products and mobile-based learning of football referee signals are developed based on the answers to the students' needs for deepening the game rules material and football referee signals, 2) Implementation of this product, which have the aim of helping students in understanding the game rules and refereeing material which is one of the materials in the football coaching course, 3) Game rules products and mobile-based learning of football referee signals are recognized as an application that can be installed on a smartphone.

\section{REFERENCES}

[1] International Telecommunication Union, "ICT Fact and Figures 2016." ICT Data and Statistics Division, Telecommunication Development Bureau, International Telecommunication Union, Jun 2016, [Daring]. Tersedia pada: http://www.itu.int/en/ITUD/Statistics/Documents/facts/ICTFactsFigures2016.pdf.

[2] Statista, "Number of mobile devices worldwide 2020-2024," Statista, 2016. https://www.statista.com/statistics/245501/multiple-mobiledevice-ownership-worldwide/ (diakses Okt 23, 2020).

[3] Asosiasi Penyelenggara Jasa Internet Indonesia, "Penetrasi \& Perilaku Pengguna Internet Indonesia: Survey 2017." Asosiasi Penyelenggara Jasa Internet Indonesia, 2017, Diakses: Okt 23, 2020. [Daring]. Tersedia pada: https://web.kominfo.go.id/sites/default/files/Laporan\%20Survei\%20 APJII_2017_v1.3.pdf.

[4] Pew Research Center, "Demographics of Mobile Device Ownership and Adoption in the United States," Pew Research Center: Internet Science \& Tech, 2017. https://www.pewresearch.org/internet/factsheet/mobile/ (diakses Okt 23, 2020).

[5] J. Poushter, "Smartphone Ownership and Internet Usage Continues to Climb in Emerging Economies," Pew Research Center's Global Attitudes Project, $\quad$ Feb 22, 2016. https://www.pewresearch.org/global/2016/02/22/smartphoneownership-and-internet-usage-continues-to-climb-in-emergingeconomies/ (diakses Okt 23, 2020).

[6] H. Crompton dan D. Burke, "The use of mobile learning in higher education: A systematic review," Computers \& Education, vol. 123, hlm. 53-64, Agu 2018, doi: 10.1016/j.compedu.2018.04.007.

[7] B. Klimova dan P. Poulova, "Mobile Learning in Higher Education,' adv sci lett, vol. 22, no. 5, hlm. 1111-1114, Mei 2016, doi: 10.1166/asl.2016.6673.

[8] B. Ligi dan B. W. D. Raja, "Mobile Learning In Higher Education," International Journal of Research - Granthaalayah, vol. 5, no. 4, Apr 2017, doi: 10.5281/ZENODO.569363.

[9] D. Mcconatha, M. Praul, dan M. J. Lynch, "Mobile Learning in Higher Education: An Empirical Assessment of A New Educational Tool," The Turkish Online Journal of Educational Technology TOJET, vol. 7, no. 3, hlm. 15-21, Jul 2008.

[10] F. Ke dan Y.-C. Hsu, "Mobile augmented-reality artifact creation as a component of mobile computer-supported collaborative learning," The Internet and Higher Education, vol. 26, hlm. 33-41, Jul 2015, doi: 10.1016/j.iheduc.2015.04.003.

[11] W.-H. Wu, Y.-C. Jim Wu, C.-Y. Chen, H.-Y. Kao, C.-H. Lin, dan S.H. Huang, "Review of trends from mobile learning studies: A metaanalysis," Computers \& Education, vol. 59, no. 2, hlm. 817-827, Sep 2012, doi: 10.1016/j.compedu.2012.03.016.

[12] F. Khalil-Ur-Rehman dan M. Farooq, "Deployment of Mobile Learning in Advanced Education Foundations," hlm. 13, 2018
[13] C. O’Malley dkk., Guidelines for learning/teaching/tutoring in a mobile environment. 2005.

[14] A. Yassine, M. Berrada, A. Tahiri, dan D. Chenouni, "A CrossPlatform Mobile Application for Learning Programming Basics," International Journal of Interactive Mobile Technologies (iJIM), vol. 12, no. 7, Art. no. 7, Nov 2018.

[15] E. Turban dan D. King, Electronic Commerce 2012: Managerial and Social Networks Perspectives. Pearson Education, 2011.

[16] K. C. Li, L. Y. Lee, S. Wong, I. S. Yau, dan B. T. Wong, "Evaluation of mobile learning for the clinical practicum in nursing education: application of the FRAME model," J Comput High Educ, vol. 31, no. 2, hlm. 290-310, Agu 2019, doi: 10.1007/s12528-019-09213-2.

[17] S. S. Oyelere, "Design, development, and evaluation of a mobile learning application for computing education," hlm. 29, 2018.

[18] L. M. Jeno, P. J. C. Adachi, J.-A. Grytnes, V. Vandvik, dan E. L. Deci, "The effects of m-learning on motivation, achievement and well-being: A Self-Determination Theory approach," British Journal of Educational Technology, vol. 50, no. 2, hlm. 669-683, 2019, doi: 10.1111/bjet.12657.

[19] M. Ali, "Pengembangan Media Pembelajaran Interaktif Mata Kuliah Medan Elektromagnetik," Jurnal Edukasi Elektro, vol. 5, no. 1, hlm. 8, 2009.

[20] I. Falahudin, "Pemanfaatan Media dalam Pembelajaran," no. 4, hlm. 14,2014

[21] T. Nurseto, "Membuat Media Pembelajaran yang Menarik," Jurnal Ekonomi dan Pendidikan, vol. 8, no. 1, Art. no. 1, 2011, doi: 10.21831/jep.v8i1.706.

[22] R. Rafiuddin, M. Basri, dan M. Azis, "Urgensi Penggunaan Media dalam Proses Pembelajaran Bagi Guru Sekolah Dasar Wilayah II Kecamatan Sanrobone Kabupaten Takalar Provinsi Sulawesi Selatan," dipresentasikan pada Seminar Nasional Teknologi Pembelajaran dan Pendidikan Dasar, Malang, 2017, Diakses: Okt 23 , 2020. [Daring]. Tersedia pada: http://pasca.um.ac.id/conferences/index.php/sntepnpdas/article/view/ 856.

[23] T. Georgiev, E. Georgieva, dan A. Smrikarov, M-learning-a new stage of e-learning, vol. 4. 2004, hlm. 5.

[24] J. M. Gambo, N. T. Bahreman, D. Watties-Daniels, M. Neal, dan S M. Swoboda, "Can Mobile Technology Enhance Learning and Change Educational Practice?:" CIN: Computers, Informatics, Nursing, vol. 35, no. 8, hlm. 375-380, Agu 2017, doi: 10.1097/CIN.0000000000000380.

[25] A. Kukulska-Hulme, "Will mobile learning change language learning?," ReCALL, vol. 21, no. 2, hlm. 157-165, Mei 2009, doi $10.1017 / \mathrm{S} 0958344009000202$

[26] J. Traxler, "Defining Mobile Learning," 2005, hlm. 7.

[27] N. Bukharaev dan A. W. Altaher, "Mobile Learning Education has Become More Accessible," American Journal of Computer Science and Information Technology, vol. 5, no. 2, Okt 2017, doi: 10.21767/2349-3917.100005

[28] L. J. Belle, "An Evaluation of a Key Innovation: Mobile Learning," Academic Journal of Interdisciplinary Studies, vol. 8, no. 2, hlm. 3945, Jul 2019, doi: 10.2478/ajis-2019-0014.

[29] T. H. Brown dan L. S. Mbati, "Mobile learning: Moving past the myths and embracing the opportunities," IRRODL, vol. 16, no. 2, Apr 2015, doi: 10.19173/irrodl.v16i2.2071.

[30] D. Nestel $d k k$., "Evaluation of mobile learning: Students' experiences in a new rural-based medical school," BMC Med Educ, vol. 10, no. 1 hlm. 57, Des 2010, doi: 10.1186/1472-6920-10-57.

[31] D. H. Rif'ati, "Pengembangan Bahan Ajar Elektronik Berbasis Mobile Learning Pada Matakuliah Gelombang," Jurnal Pendidikan Fisika Indonesia, vol. 11, no. 2, hlm. 6, 2015.

[32] A. Kukulska-Hulme, "Mobile learning for quality education and social inclusion." UNESCO Institute, Des 2010

[33] I. García-Martínez, J. M. Fernández-Batanero, D. Cobos Sanchiz, dan A. Luque de la Rosa, "Using Mobile Devices for Improving Learning Outcomes and Teachers' Professionalization," Sustainability, vol. 11, no. 24, hlm. 6917, Des 2019, doi: 10.3390/su11246917.

[34] N. Mileva, "The Effectiveness of Mobile Learning in the Form of Performance Support System in Higher Education," Int. J. Interact. Mob. Technol., vol. 5, no. 4, hlm. 17-21, Okt 2011, doi: 10.3991/ijim.v5i4.1692. 
[35] I. K. Wijaya, R. A. Bakri, A. A. Wutun, F. Fitriani, dan A. A. Mattoliang, "The Effectiveness of Mobile Learning Based Android in Learning English Vocabularies," International Journal of Interactive Mobile Technologies (iJIM), vol. 13, no. 12, Art. no. 12, Des 2019.

[36] M. I. Yousuf, "Effectiveness of Mobile Learning in Distance Education," Turkish Online Journal of Distance Education-TOJDE, vol. 8, no. 4, hlm. 12, Okt 2007. 